\title{
The Federal Open Market Committee in 1973
}

\author{
ANATOL BALBACH and JERRY L. JORDAN
}

I ALL BUT ONE meeting throughout the first eight months of 1973 , the Federal Open Market Committee (FOMC) issued a directive calling for slower growth in monetary aggregates. During the last two meetings of the year, with information on the likely consequence of the oil shortage continuing to be assessed, the Committee sought "to achieve some easing in bank reserve and money market conditions."

This annual review of FOMC decisions is intended primarily as a description of actions under varying legal, traditional, and economic constraints. The makeup of the Committee and the published intentions and instructions to the Trading Desk of the New York Federal Reserve Bank are summarized in accompanying exhibits. A brief outline of observed and projected economic conditions, as presented in various documents, ${ }^{1}$ is discussed in conjunction with actions taken at that time.

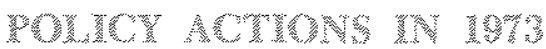

At the time of the FOMC meeting in January 1973, the United States was experiencing one of the strongest economic recoveries in its recorded history. At the end of 1972, gross national product was up 10.8 percent from a year earlier, which consisted of a 7 percent growth in output and a 3.3 percent increase in the price level. Employment rose at an umprece dented rate of 3.3 percent and unemployment declined to 5.1 pereent. A strong demand for credit manifested itself in an annual increase of bank oredit of 14 percent over the year and, in spite of the 7.7 percent increase in the narrowly defined money stock $\left(\mathrm{M}_{1}\right)$, the prime rate still rose from 5.25 percent in late December 1971 to 5.75 percent in December 1972. Over the same period the market yield

The "Record of Policy Actions," Federal Reserve Bulletin (April 1973-10brary 1974). "Financial Developments" for the four quaters of 1973, Federal Reserve Bulleth (April, August, November 1973, and Fobruary 1974 ).

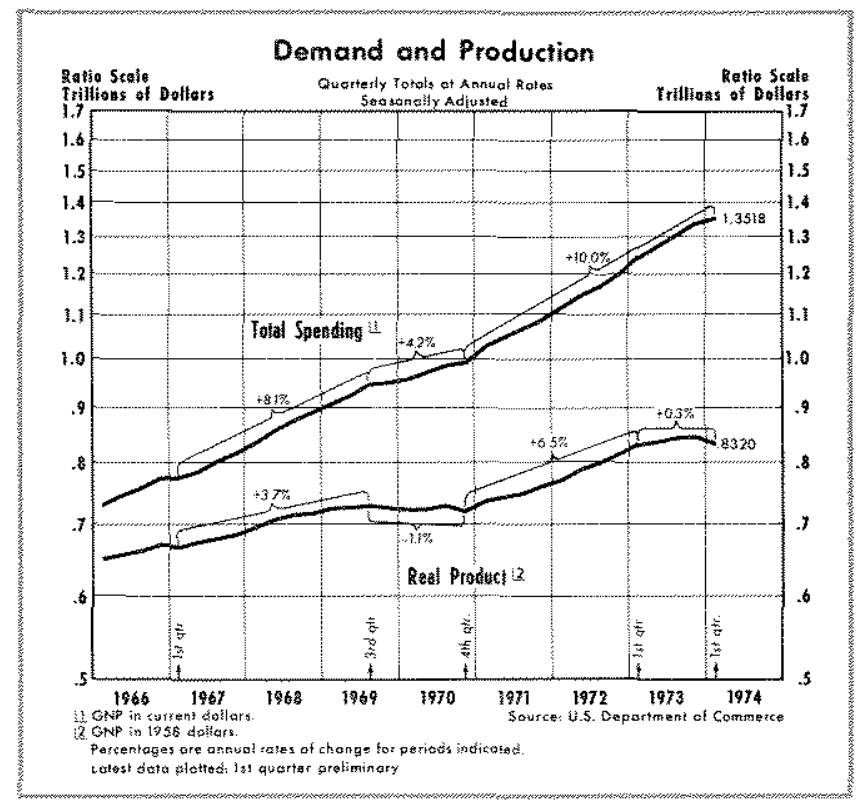

on Treasury bills rose from about 4 to just over 5 percent, and the Federal funds rate rose from 4,14 to 5.33 percent.

The economic expansion of 1972 was marred by anticipations of reemerging inflation. In 1973 price rises did indeed accelerate and were accompanied by a rapid rise in interest rates. Concern with inflation and the high cost of credit became widespread early in the year. On numerous occasions in various publio sources it was referred to as the major problem facing the economy.

A higher rate of infation, particulary during the first part of this year which now seems likely, is bound to endanger the outcome of the many wage negotiations that will begin this spring. A low rate of inflation is a necessity for assuring labor to accopt moderate waye increases.

Unortunately, the assurance that must be offered to labor is the promise that mnation will again moderate sometme by the end of the year and not the denonstrable fact that inflation has been sum- 


\section{Organization of the Committee in 1973}

The Federal Open Market Committee (FOMC) consists of the seven members of the Federal Reserve Board of Governors and five of the twelve Fed. eral Reserve Bank Presidents. The Chairman of the Board of Governors is also, by tradition, Chairman of the Committee. The President of the New York Federal Reserve Bank is a permanent member of the Committee and, also by tradition, is its Vice-Chairman. All other Federal Reserve Bank Presidents attend the meetings and present their views, but votes may be cast by only four of these Presidents, who serve as members for one-year terms on a rotation basis.

Members of the Board of Governors for most of 1973 included Chairman Arthur F. Burns, George W. Mitchell, Andrew F. Brimmer, Jeffrey M. Bucher, J. Dewey Daane, Robert C. Holland, and John E. Sheehan. Federal Reserve Board Governor and ViceChairman J. L. Robertson resigned from the Board April 30, 1973. On May 17 George W. Mitchell was designated Vice-Chairman of the Board. Governor Robert C. Holland assumed his office June 11 to fill the unexpired term of Governor Robertson. In addition tu Alfied Hayes, Piesident of die Federal Reseive Bank of New York, the following Presidents served on the Committee during January and February 1973: Philip E. Coldwell (Dallas), David P. Eastburn (Philadelphia), Bruce K. MacLaury (Minneapolis), Willis J. Winn (Cleveland). In March the Committee was reorganized and the four rotating positions were filled by the following members: John J. Balles (San Francisco), Darryl R. Francis (St. Luuis), Robert P. Mayo (Chicago), and Frank E. Morris (Boston).

The Committee met regularly once each month during 1973 to discuss economic trends and to decide upon the future course of open market operations. As in previous years, occasional telephone or telegram consultations were held between regular meetings. Additional policy actions for subsequent weeks and months were generally discussed at these interim meetings. During each regular meeting, a directive was issued to the Federal Reserve Bank of New York stating the general ernnomic goals of the Committer. and providing general guidelines as to how the Manager of the System Open Market Account ${ }^{1}$ at the New York Federal Reserve Bank should conduct open market operations to achieve these goals. Each directive contained a short review of economic data considered and the general economic goals sought by the Committee. The last paragraph gave operating instructions to the Account Manager. These instructions were stated in terms of bank reserve and money market conditions which were considered consistent with the achievement of desired growth rates of monetary aggregates. Any special factors, such as Treasury fi nancing operations, were also taken into account.

1The Manager of the System Open Market Account may
be referred to as the "Account Manager" and the Trading be referred to as the "Account Manager" and the Trading
The decisions on the exact timing and amount of daily buying and selling operations of securities in fulfilling the Committee's directive are the responsibility of the Account Manager at the Trading Desk of the New York Bank. Each morning, he and his statt decide what open market operations, if any, are to be undertaken that day. In developing this program, money and credit market conditions and aggregate targets desired by the Committee are considered, as well as other factors which may be of concern at that time. Each morning in a conference call, the Account Manager informs one voting President and staff members of the Board of Governors about present market conditions and open market operations which he proposes to execute that day. Other members of the Cornmittee are informed of the daily program by wire summary.

A summary of the Committee's actions is presented to the public in the "Record of Policy Actions" of the Federal Open Market Committee. The "Record" for each meeting is released about 90 days after the meeting and is published in both the Annual Report of the Board of Governors of the Federal Reserve System cach sping and in the Federal Reserve Bulletin each month. The "Record" for each meeting generally includes:

1) a staff summary of recent economic developments, such as prices, employment, industrial production, and components of the national income accounts; projections concerning real output growth for one or two quarters ahead; and prospective financial developments;

2) a discussion of the U.S. balance of payments and international financial developments;

3) a discussion of interest rate movements;

4) a discussion of open market operations and growth of reserve aggregates since the last meeting;

5) a discussion of the movements of monetary aggregates such as $M_{1}$ and $M_{2}$, and the adjusted credit proxy ${ }^{2}$;

6) conclusions of the FOMC;

7) a policy directive issued by the FOMC;

8) a list of the voting position of members and any dissenting comments;

9) a description of any actions and consultations that may have occurred between the regularly scheduled meetings.

$2 \mathrm{M}_{1}$ refers to the money stock, defined as private demand deposits plus currency in the hands of the nonbank public. $\mathrm{M}_{2}$ refers to money stock plus net time deposits; net time deposits are defined as total time deposits at all commercial banks minus large time certiticates of deposit at large weekly reporting commercial banks. Adjusted credit proxy is defined as member bank deposits subject to reserve requirements plus bank-related commercial paper, Eurodollar borrowings of U.S. banks, and certain other nondeposit items. 
ciently checked. . . [Wilbur D. Mills, New York Journal of Commerce, February 8, 1973]

However, with labor and capital resources being utilized more fully, the expanding demand for goods and services could begin to pull prices upward and thereby reinforce prevailing cost-push pressures. In the absence of monetary and fiscal restraint, excess aggregate demand might easily re-emerge and touch off a new round of inflation.

This must not be permitted to happen. The hardwon gains our Nation has made in the struggle against inflation must not be frittered away. To do so would sap the confidence of our people in the integrity of government. [Arthur F. Burns, Statements to Congress, Federal Reserve Bulletin (March 1973), pp [64-68]

In addition to the inflationary problems which underscored the course of 1973 , the predictable decline in the growth rate of real product began to take place. The rate of growth of output in 1972 had been almost double its long-term trend, and the decline in the rate of growth was inevitable. This became quite apparent in the middle of 1973 when reported shortages of intermediate goods began to develop, reflecting capacity constraints and misallocation of resources generated by price and wage controls. The announcement of the Arab oil boycott in October was interpreted as a factor which would create a decline in energy supplies and would further exacerbate the decline in production. The FOMC staff correctly projected this decline and the Committee took this projection into consideration. It is important to emphasize that this projected decline in the growth of output was attributed by some to supply considerations, rather than to the decline in demand which normally accompanies recessionary periods.

Meanwhile, inflation continued on its upward path. There were many different factors to which the acceleration of prices was attributed:

But as the Fates would have it, several unusual factors combined to impart a new dimension to our inflationary problem this year. First, the devaluation of the dollar not only resulted in higher prices of imported goods, but also affected our price level by leading to some substitution of domestic for foreign products and by imparting a sharp impetus to foreign demand for our products. Second, otir economic expansion has been accompanied by rapid expansion in virtually every other industrial country. The worldwide demand for capital equipment and industrial materials - goods for which the United States is a major supplier - has therefore burgeoned. Third, our current ability to expand output of basic industrial materials is narrowly limited - in large part because investment by producers of key materials has been held back in recent years by unsatis-

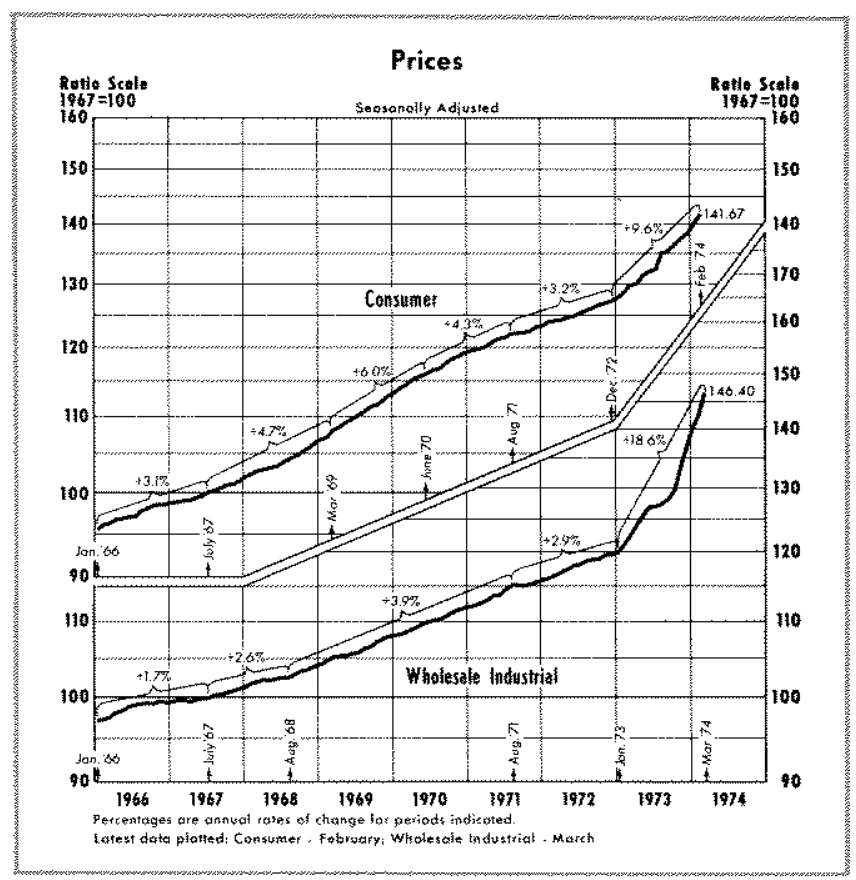

factory profits and new environmental controls. Fourth, bad weather in a number of countries severely restricted agricultural production last yearat the very time when the demand for foodstuffs was rising rapidly in response to the worldwide expansion of incomes and employment. The concatenation of these special factors has played a decisive role in driving up prices this year. [Arthur F. Burns, "Objectives and Responsibilities of the Federal Reserve System," Federal Reserve Bulletin (September 1973), p. 655]

In spite of these special considerations, the Committee apparently felt that a rapid growth of the money stock could have been a contributing factor ${ }^{2}$ and repeatedly voted to restrain the expansion of monetary aggregates.

As discussed in the "Record of Policy Actions" of the Federal Open Market Committee, the Committee's staff reported increases in the price level at every meeting, and proiected further increases in February and the last four months of the year. Given the economic conditions at the beginning of the year, developments during 1973, and the staff projections of a decline in money demand because of the cumula-

\footnotetext{
2 At present there is no real alternative to a restrictive monetary policy. To be sure, if we permitted money and credit to expand at a more rapid pace, short-term interest rates would decline for a brief period. But in so doing we would be adding fuel to the inflationary fires now raging. Before very long interest rates would rise again, and probably well beyond their present level, as both lenders and borrowers adjusted to the quickened pace of inflation. The simple and inescapable truth is that inflation and high nominal interest rates go together." [Arthur $F$. Burns, "Objectives and Responsibilities of the Federal Reserve System," Federal Reserve Bulletin (September 1973) p. 656]
} 


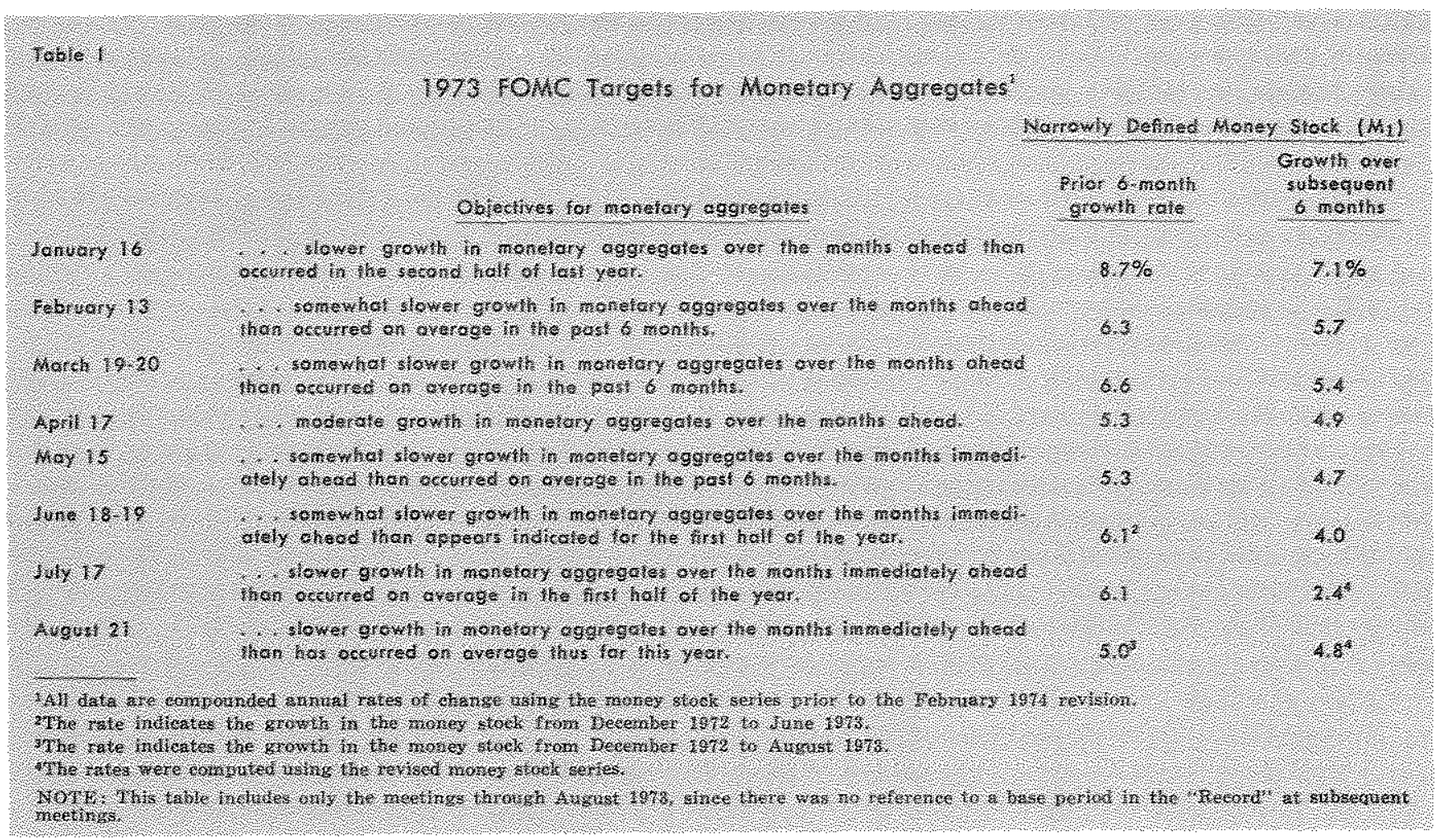

tive impact of rising interest rates, the Committee voted for slower growth of monetary aggregates in all of its meetings between January and August with the exception of April. On seven occasions the FOMC called for a slower growth than had occurred over the previous six months. And, indeed, if the results of these actions were expected to become effective over an approximate span of the subsequent six months, the Committee's actions can be interpreted as having been successful (see Table 1). In April and in the last four months of the year, the staff projected moderate growth in the demand for money and the Committee adopted a directive indicating a desire to achicve moderate growth in monetary aggregates.

Growh of the namowly defined money stock during 1973 can be divided into two periods: in the frrst half of the year money grew at a 7.4 percent annual rate, as measured from the last quarter of 1972 to the second quarter of 1973; in the second half the growth was 4.8 percent from the second quarter of 1973 to the fourth quarter of 1973. When the trend is measured from the first quarter of 1970 to the fourth quarter of 1973, this sharp change in the growth rate of $M_{1}$ reduced the average growth of money only from 7.0 to 6.7 percent.

Although the growth of monetary aggregates slowed as desired, month-to-month growth was highly volatile; it varied from a 15.1 percent annual rate of growth in the May/June period to a 3.5 percent annual rate of decline in August/September. Such volatility has been atributed to many factors ${ }^{3}$ which were operating in the economy in 1973. These erratic short-run movements were resisted by the Committee, and between meetings the Committee was consulted nine times when the growth of the aggregates seemed to fall outside acceptable ranges. In all cases but three,

$3^{\prime \prime}$ Soen after the April neeting, it appeared that the mone" tary aggregates would grow in the April-May period at rates in excess of an accoptable range even though estimates suggested that reserves avalable to support private nonbank deposits (RPD's) wonld grow in that period at an annual rate below the range of 10 to 12 per cent specified by the Conmittee. The dvergent tendencles were attributed to two main factors: Banks' excess reserves were lower than anticipated and currency in circulation was growing, more rapidy than expected." [thecord of policy Actions of the Federal Open Matket Commitiee, Federal Reserve Bulletin (August 1973), p. 577)

"The narrowly defned money stock (MI), after changing little over the thind quarter, grew moderately in October and rapidly in November. It appeared that the November rate of growth had been affected by such temporary infuences as expansion in precautionary balances held by the public in response to the new economic uncertaintes and increases in deposits of foreign commercial and central banks." [Mbid, Federal Reserve Bullein (February 1974), p. 116.]

Also see "Financial Developments in the First Quarter of 1973," Federal Reserve Bubletin (May 1973), and p. 9 of this Revicw; "Financial Developments in the Second Quarter of 1973," "ederal Reserve Bullein (August 1973), and pp. 9-10 of this Rewew; and "Record of Policy Aetions" of the Federal Open Market Commitee, Federal heserve Bulletin (August 1973) and (February 1974), and p. 17 of this Reviets. 
the Committee agreed to adjust money market conditions in order to move monetary aggregates into the desired range; in the three remaining cases it agreed to maintain current money market conditions in view of the sensitive state of financial markets and the general economic situation.

There is no doubt that the growth of the money stock slowed in 1973 as compared with 1972. This outcome is consistent with the expressed desires of the Federal Open Market Committee. The process by which the decline occurred is subject to alternative interpretations. Since causality is based on some analytical framework, and there is no consensus as to the correct framework for analyzing monetary growth, alternative interpretations are possible. The following section analyzes the movements in monetary aggregates in greater detail and offers alternative explanations of the factors contributing to the observed growth.

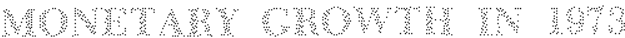

On January 31, 1974, the Board of Governors of the Federal Reserve System released revised data for currency held by the public, demand deposits held by the public, and time deposits at all commercial banks. This revision included adjustments based on new benchmark data for nonmember bank deposits and vault cash, and the amnual recomputation of seasonal adjustment factors which are applied to each basic deposit and eurrency series.

The pattern of monetary growth in 1973, as indicated by the data available to policymakers throughout the year, is compared with the pattern of growth displayed with the revised series. This comparison is useful since actual results of policy actions might be interpreted differently in light of the revised data. Generally, the revised series for monetary aggregates show that the increases in the narrowly defined and broadly defined money stock in 1973 were greater than previously reported.

This section provides two approaches to analyzing some of the factors influencing movements in money throughout the year. One approach is essentially supply-oriented and employs a concept referred to as the "monetary base". The other approach implies that factors affecting the demand for money and credit are also important in the money supply process.

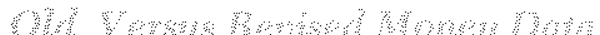

Table II illustrates the differences in the growth of money stock and the monetary base for threemonth periods in 1973, and the differences between

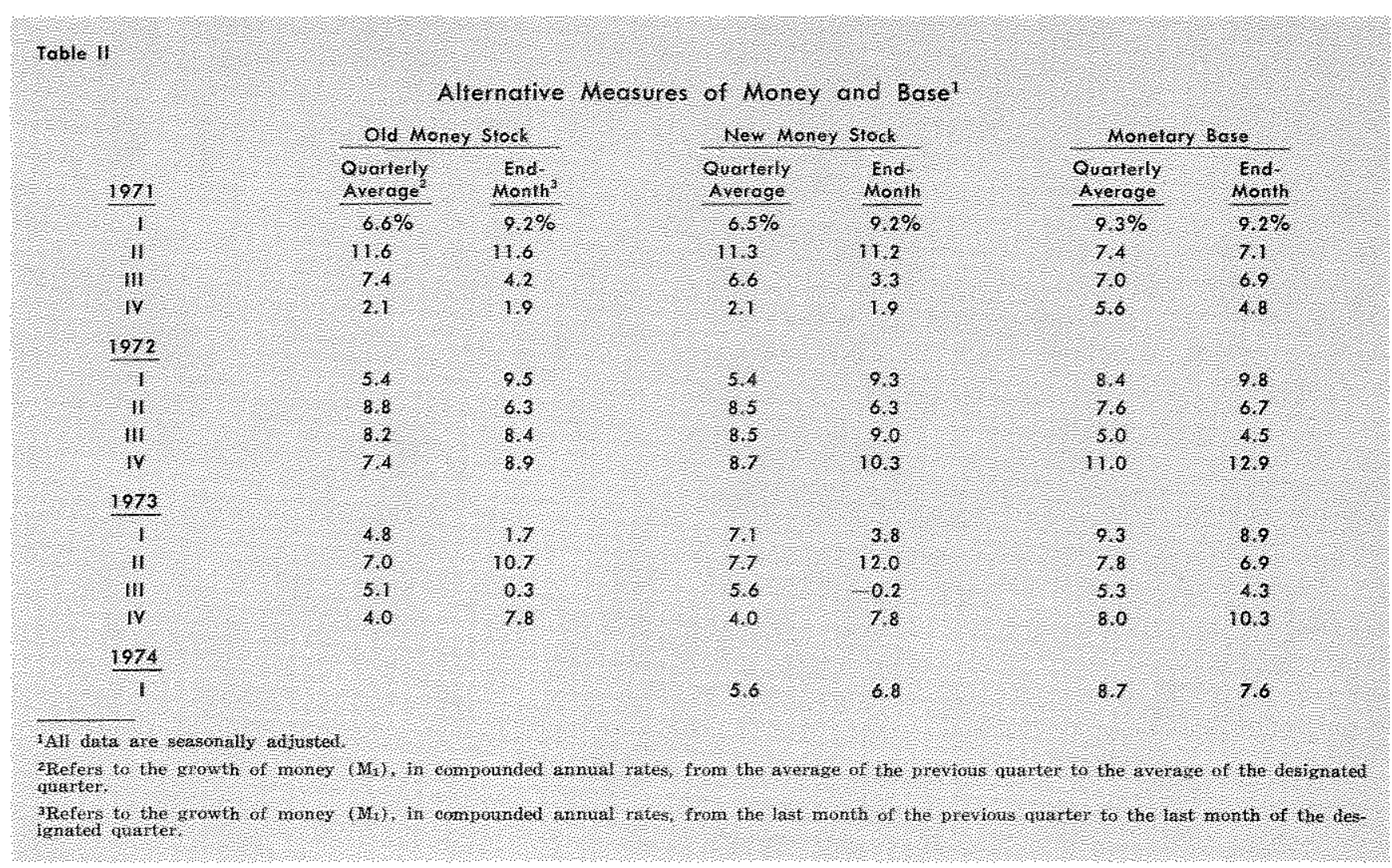


the old and new series of money. The table also shows growth rates based on three-month (quarterly) averages of successive quarters and on the end-months of successive calendar quarters.

The end-month figures for both the old and new series show essentially the same pattem, especially in 1973. Beginning in late 1972 they leave the impression that the pattern of money growth from one quarter to the next was fast-slow - fast - slow - fast. Since the data are seasonally adjusted, one would not expect such a repetitive patten in the adjusted data to persist for a prolonged period of time, even if it prevailed in the raw data.

The growth of money in 1973, as indicated by the quarterly average figures, reveals a different pattern in the new series as compared to the old. Referring to the old series, the 4.8 percent rate of increase for the first quarter of 1973 appeared to indicate a significant slowing from previous money growth rates, although less than the 1.7 percent rate of growth on an end-month basis. Either figure was clearly in the direction consistent with the directive shown in the "Record" for the meetings in early 1973 which called for achieving "slower growth in monetary aggregates." Under the new data series, however, the 7.1 and 7.7 percent rates of money growth recorded in the first two quarters of 1973 , respectively, were only marginally slower, on average, than the growth that had prevaled in the recent past. Thus, by mid-1973 the average growth rate of money for three years was 7 percent, the fastest growth for such a period since World War II.

The figures for the fourth quarter of 1973 lead to a somewhat ambiguous interpretation of the path of monetary growth. On a quarterly average basis, both the new and old series show further slowing in the growth of money from the rate registered in the third quarter. In contrast, the growth rate of money indicated by the end-month igures shows a sharp reacceleration. The difference in interpretation of monetary growth caused by data revisions or by different time spans can be clarified by reference to other theoretically-related series. The concept of the monetary base is used here to aid in assessing the pace of monetary growth. ${ }^{4}$

By definition, the base is the "net monetary liabilities of the govemment sector" or the non-interest

The monetary base is also referred to as high-powered money or demand debt of the govemment. bearing debt of the Treasury and the Federal Reserve Banks. The derivation and uses of the concept are reviewed elsewhere.

Table III shows average growth rates of money and the base over four-quarter petiods. Literally, the figures shown are the percentage changes from the corresponding quarter a year earlier. It is clear that the deceleration in the growth of money at the end of 1973 (both narrowly and broadly defined) is much more pronounced than for the monetary base. The

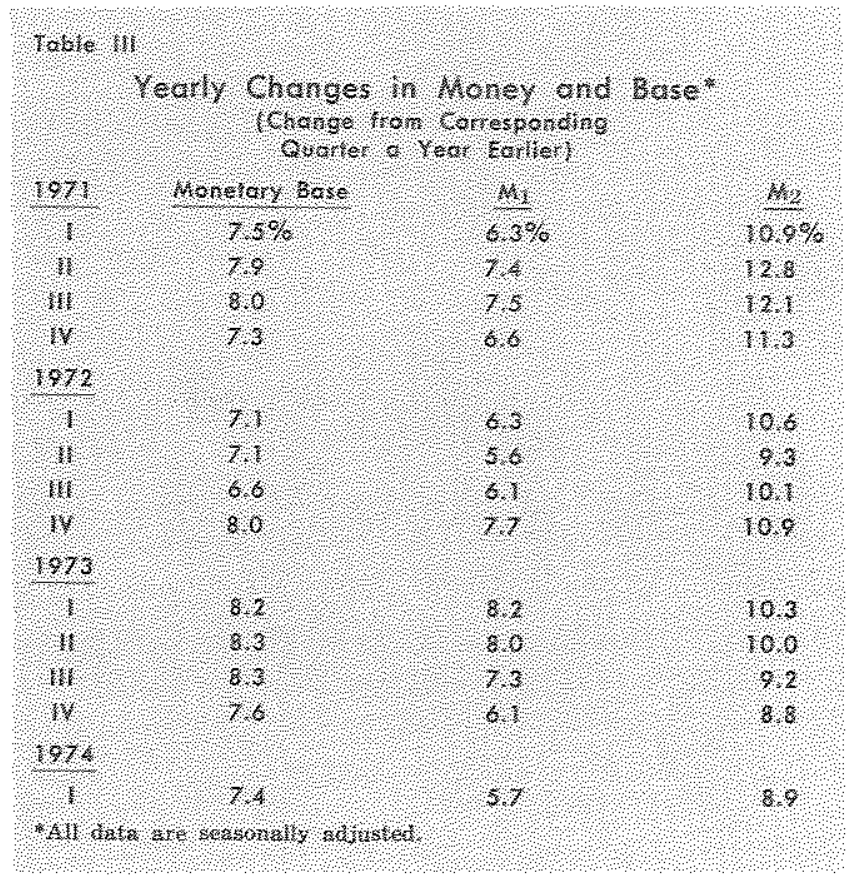

divergence in the growth rates of the narrowly defined money stock and the monetary base observed at the end of 1973 is greater than occurs normally, and previous data indicate that such a divergence is not likely to persist for any extended period. ${ }^{6}$ This "gap" would be expected to close as a result of a reacceleration in the growth of money, a slowing in the growh of the nonetary base which would, in effect,

3For a more detaled discussion of the monetary base, see Leonall C. Andersen and Jerry L. Jordan, "The Monetary Base - Explanation and Analytical Use, this Review (OCtober 1969), pp, 10-19; Jane Anderson and Thomas $M$. Humphrey, "Deterninants of Change in the Money Stock: 1960-1970," Monthly Review, Federal Reserve Bank of Pichmond (March 1972), pp. 2-8; fohn D. Rea, "Sonrces of Money Growth in 1970 and 1971 ," Monthly Rewiew, Fed eral Reserve Bank of Kansas City (July/August 1972), po. $3-13$

SThe monetary base and the money stock are retated through a "multiller": $\mathrm{M}=\mathrm{mB}$, where $\mathrm{M}$ is the money stock, $\mathrm{B}$ is the monetary base, and $\mathrm{m}$ is the multiplier. The growth rates of money and base are isnally similar over periods of a year or more, which means that he multiplier is relatively constant. Factors which cause short-run fluctuations in the multiplier inchule changes in time deposts and U.S. Treas. ury deposits at member banks. For a detailed exposition 


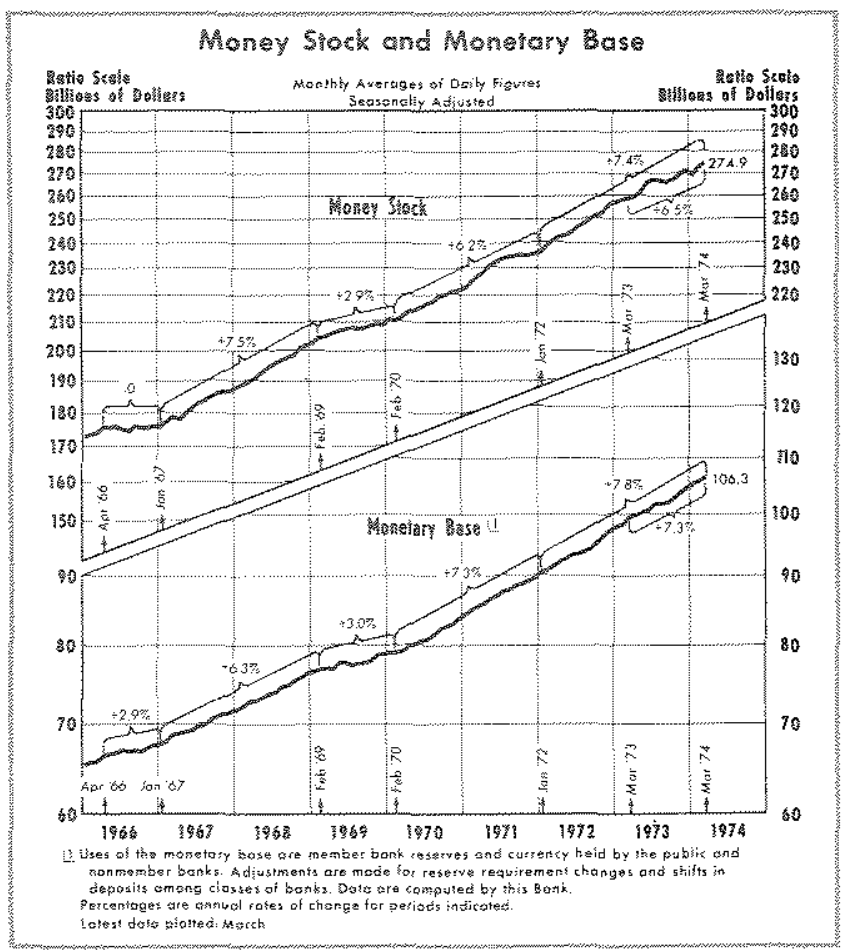

ratify or confirm the slowing in money growth, or by a combination of these developments.

The growth rates of money and the monetary base are shown in the acompanying chart. The growth of the base in 1973 was about the same as the average rates of growth over the past two- and fonr-year periods. The factors contributing to the continued growth of the base in 1973 are shown in Table IV. Clearly, the rise in the monetary base in 1973 occurred manly as a result of the large increase in the Federal Reserve portolio of U.S. Government securites. The other single factor contributing significantly to the growth of the base was related to the monetization of gold following the rise in its official price from $\$ 38$ per ounce to $\$ 42.22$ per ounce. ${ }^{t}$

The significant factor explaining the slower growth of the narowly defined money stock, as compared to the monetary base, last year is shown in the line entilled "Base Absorbed by Time Deposits" in Table IV. The increase in required reserves against time deposits at member banks absorbed 27.9 percent of the

of the "model" relating the monetary base and the money stock see Albert 5 . Burger, The Money Supply Process (Beinont, Calfornia: Wadsworth Publishing Company, Ine., 1971), and Tobert $E$. Weintraub, Introduction to Monetary Fconomics; Monel, Banking, and Economic Activity (New Tork: Ronild Press Co., 1970 ).

TFor a detaled andysis of the monetary effects of the devaluation and monetization of the increased valte of the gold swok, see Aber $\mathrm{E}$. Burger, "The Monetary Economics of Gold, this hevew (January 1974), pp. $2 * 7$. rise in the monetary base last year, compared with 19 percent a year earlier. Thus, the base available to support growth of $\mathrm{M}_{1}$ in 1973 rose 6 percent very similar to the 6.1 percent rise in the money stock.

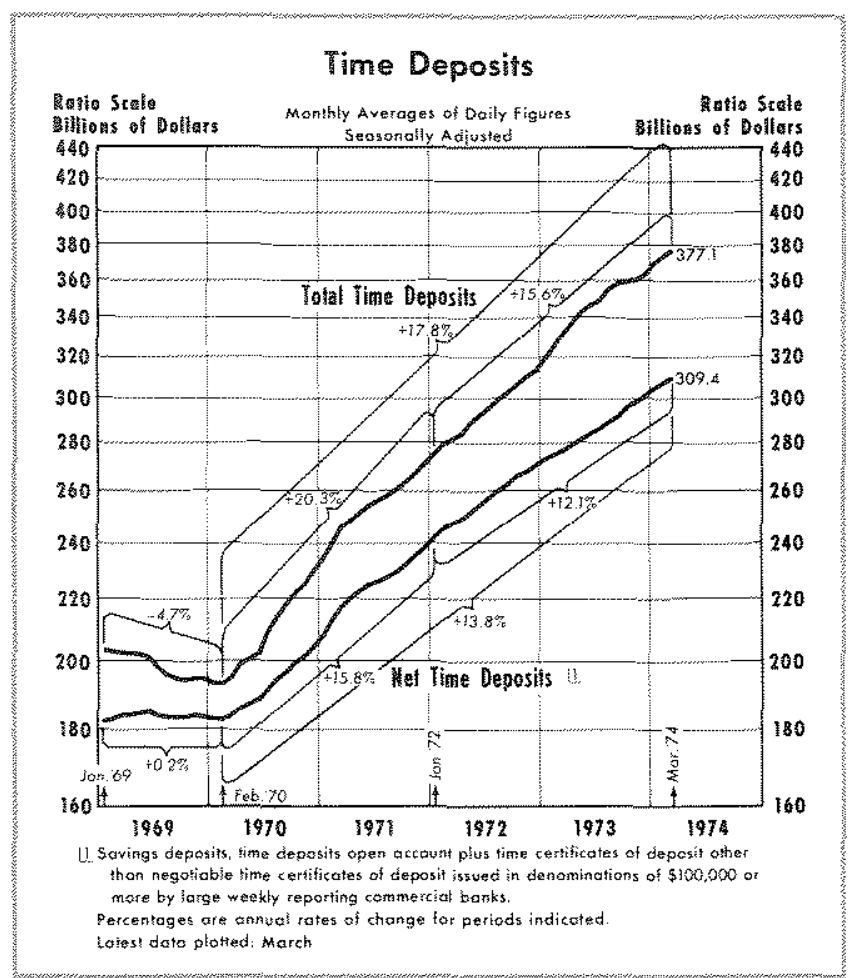

This approach to analyzing money growth leads to the conclusion that since the rise in the base in 1973 was only slightly slower than in 1972 , the slower growth in money is attributable to the very large rise in total time deposits at member banks and the reserves that were thereby absorbed. The term "supply-oriented" is applied to this approach since the "linkage" is from open market reserve-supplying operations to the total monetary base and, given the amount of reserves absorbed by time deposit growth, to the money stock.

The implication for monetary control is that open market reserve-supplying operations, under the direction of the FOMC, are a primary determinant of the growth of the money stock. Open market operations in 1973 increased the monetary base at about the same rate as in 1972; however, the much more rapid growth of time deposits in 1973 resulted in a slower growth of the narrowly defined money stock.

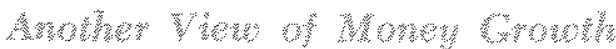

Official public documents discussing monetary and financial developments, such as the "Record of Policy Actions," and the quarterly report of "Financial Developments" submitted to the Joint Economic Com- 


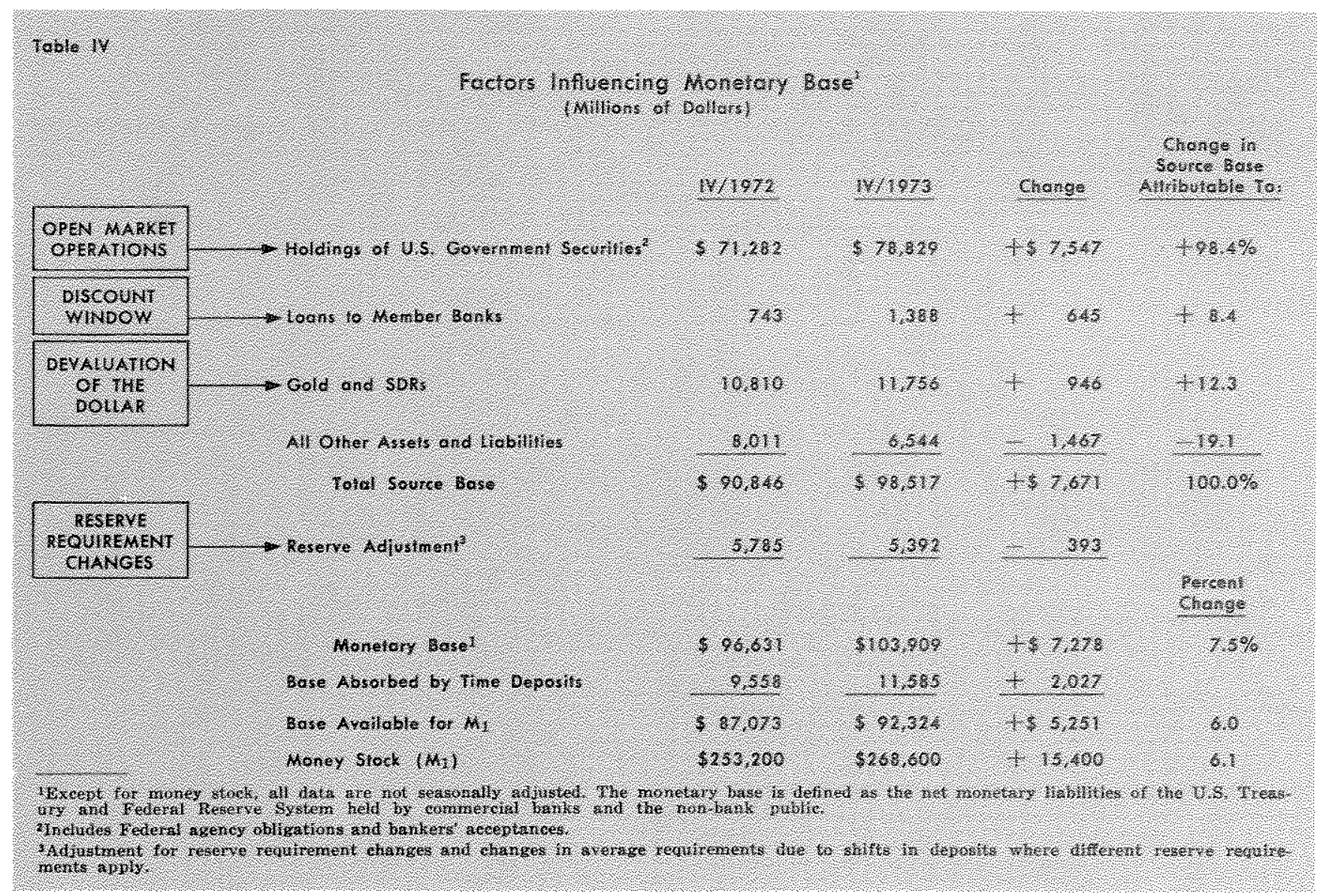

mittee (JEC) of Congress by the Board of Governors, provide analyses of the factors influencing the growth of monetary aggregates over immediate past periods. These reports also discuss factors infuencing market interest rates as well as the sources and uses of bank reserves and credit in the money and oapital markets.

In the reports to the JEC, the discussion of the growth of the money stock emphasizes factors influencing the demand for money balances and demands for credit. ${ }^{8}$ The following statements are drawn from this report. The reader should bear in mind that data for monetary aggregates were signifioantly revised in early 1974. Unless otherwise indicated, the excerpted comments refer to monetary developments on the old basis.

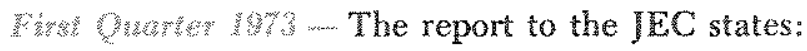

The narrowly defined money stock, $\mathrm{M}_{1}$, slowed to a 1.7 per cent annual rate of growth in the first quarter of 1973 , tending thereby to offset the rela-

FFor a detailed analysis of this framework contrasted with the monetary base approach, see Albert $E$. Burger and Neil A. Stevens, "Monetary Expansion and Federal Open Market Committee Operating Strategy in 1971," this Review (March 1972), pp. 11-31. tively rapid 8.8 per cent growth rate in the fourth quarter of 1972. For the 6 monthe together, $M_{1}$ increased at a 5.2 per cent anual rate. In the first quarter, demands for money mat have been reduced by the cumuldive impact of rising interest rates and possibly by growing concern over inflation leading to at least some temporary substivition of goods for cash. [emphasis added]

In addition, severnl special factors may have had an influence on growth of $M_{1}$ in the first quarter. In January, for example, there was some indication that demand deposits were reduced as State and local govemments shifted revenue-sharing funds, received in December, out of demand balances into time deposis. Also, in March the unusualy light wolume of business borrowing over the midmonth tar period suggests that corporations relied more heavily than usual on demand deposits as a souree of funds for their tax payments. And finally, in the midst of the intemational distubances, as noted earlier, there conld have been some minot movement of funds abroad directly out of demand deposits in February and early March. [emphasis added]

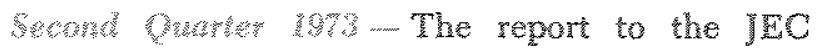
states:

When changes are measured from the end-month of the quarter, MI increased at a 1.7 per cent annual 


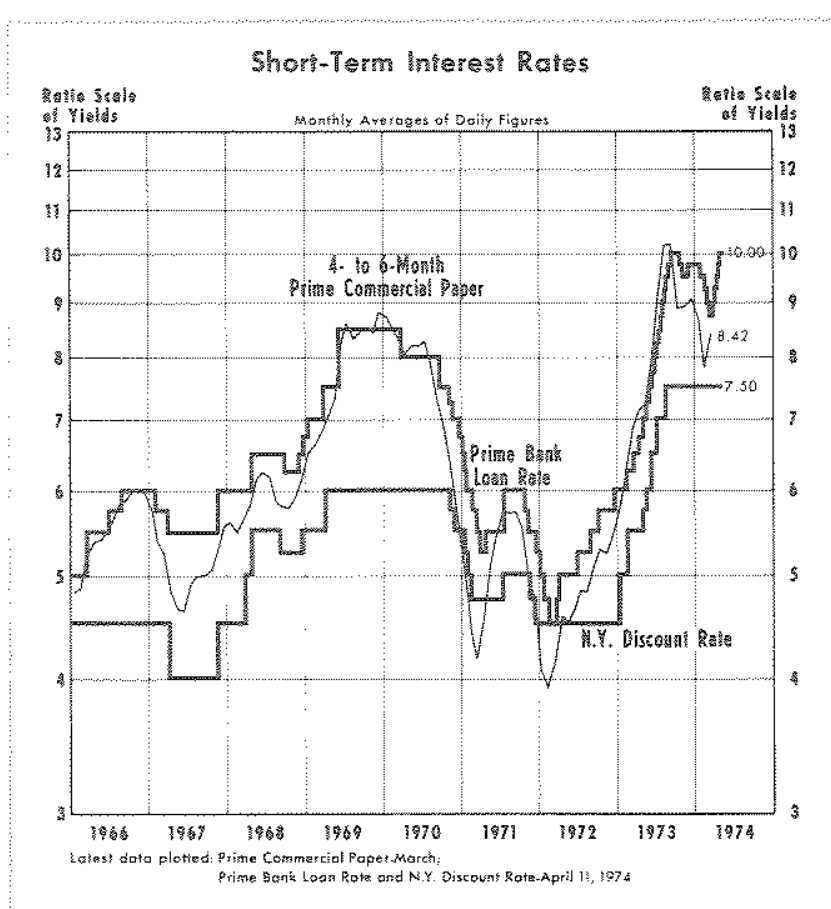

rate hine first quarter and at a 10.3 per cent rate in the second. However, when changes are measured from the average for a full guarter, rates of growth in $W_{1}$ were 4.6 per cent and 6.9 per cent for the two guarters, respectively. The cuartery average tends to smooth ont fuchations in the highly volatile $M_{1}$ series. Over the first half of the year the narrowly defined money supply grew at about a 6 per cent angual rate.

The rate of growth in $M_{1}$ was slower than might have been expected in the first quarter given the rapid increase in gross national product. Part of the slowing was apparently atributable to a drawing down of the year-end bulge in siate and local demand balances due to shiss of revenuemalaring funds into interesteaning assets. Also, during the first quarter there was some reduckion in dollar cash balances in connection with spectative ouflows into foreign curencies during the winter. In the second quarter, in addition to the continuing impact of en larged transactions demands for money by consum ers and bnsinesses, special factors such as unusually large personal income tax refunds in April and May may have contributed to the faster growth in $M_{1}$. [emphasis added]

The report to the $\mathrm{YEC}$ states:

There was a marked slackening in growh of the monetary aggregates in the thind guarter. Following a molerate rise during Jily, the narrowly defined money supply $\left(\mathrm{M}_{1}\right)$ declined in both August and September. On belnnce, $\mathrm{M}_{1}$ showed almost no gakn over the third guarter, as measured on an end-month of quarter basis from June to September. However, when changes are measured from the average for a hull guarter, $M_{9}$ expanded at a 5.1 per cent antun rate in the third guarter, only moderately slower than the 6.9 per cent pace of the second quarter. These quarterly average growth rates - which tend to smooth out fuctuations in the volatile $M_{1}$ series and are the method used for measuring related economic quantites such as GNP - are perhaps a better refection of the moderating vend in $\mathrm{M}_{1}$ growth.

The reduction in $M_{1}$ growth in the third quarter was in large part related to the lagged effect of high and rising interest rates that increased substantially the opporinity cost assoctated with holding demand balances. There also may have been one-time shifts

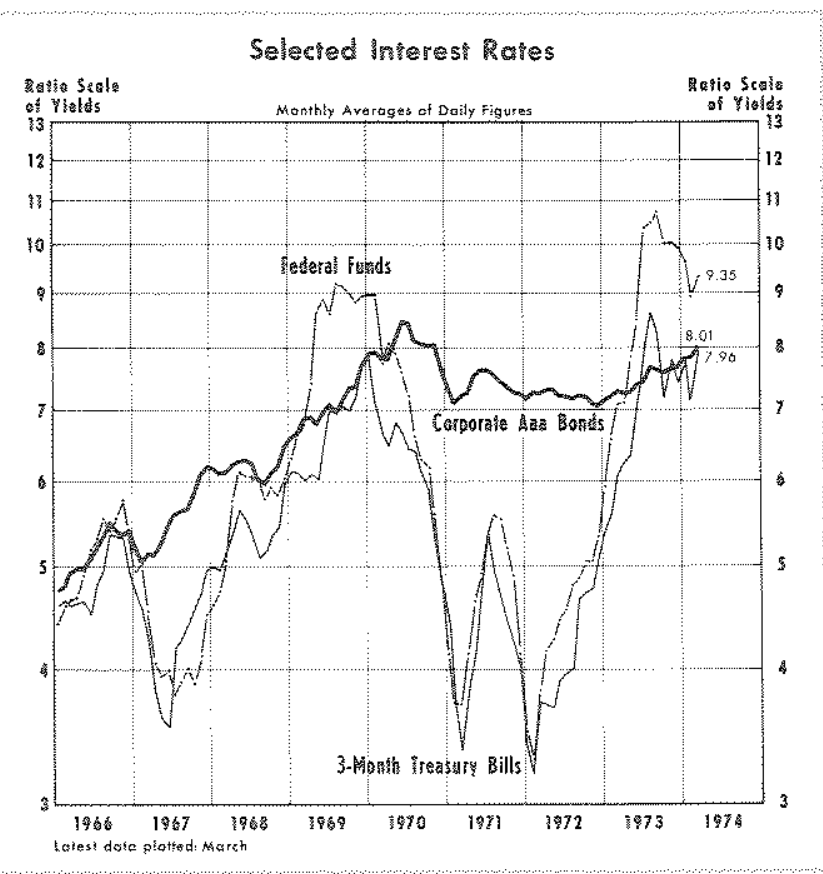

from demand balances to consumer-type time deposits following the regulatory action on deposit rate ceilings in July and the subsecuent upward adjustment of offering rates on time and savings deposits. Furthermore, in September corporations seemed to rely more heavily than in past years on demand balm ances to finance third-quarter tax payments, thus contributing to slower $\mathrm{M}_{1}$ growh late in the quarter. [emphasis added]

\section{an: The report to the IEC states:}

During the second hall of 1973 , the narrowly defoned money stock expanded at a 3.7 per cent annual rate, much slower than the 7.7 per cont growth rate of the first half. However, it grew at a relatively rapid rate in the final months of the year when public demands for cash balances may have been enhanced by precautionary motives in the unctertain financial and economic environment. The rapid $\mathrm{M}_{4}$ growh late in the year occurred with only a small increase in reserves available to support private nonbank deposits, as a reduction in large negotiable certificates of deposit (CD's) freed reserves to suppork expansion in the demand deposit component of $M_{1} \ldots$. [emphasis added] 
Measured on an end-month of quarter basis, $M_{1}$ increased at a 7.5 per cent seasonally adjusted annual rate during the fourth quarter after showing little net change in the third quarter. When meam sured on the quarterly average basis commonly employed in calculations of such economic aggregates as gross national product, the fourth-quarter growth rate of $\mathrm{M}_{1}$ was 3.9 per cent as compared with a 5.5 per cent rate for the third. $\mathrm{M}_{2}$ expanded at an annual rate of 10.1 per cent from September to December, buoyed by stronger inflows of consumertype time and savings deposits at commercial banks. $M_{3}$ rose at a 9.2 per cent rate over the period, rehecting expansion in $\mathrm{M}_{2}$ and improved deposit flows at nonbank thrift institutions. These growth rates reflect yearmend revisions in the monetary aggregates, incorporating new benchmark data for nonmember banks and updated seasonal adjustment factors. The revisions raised measured 1973 growth rates for $M_{1}$ by close to 1 per cent and for $\mathrm{M}_{2}$ and $\mathrm{M}_{3}$ by lesser amounts.

Special factors stemming primarily from the Arab oil embargo may have enlarged money stock growth late in the year. As the dollar gained strength in in temational markets because of the presumed greater impact of the fuel shortage on foreign economies, some foreign central banks sold dollar assets to support their own currencies. In November some of the proceeds of these sales were deposited temporarily at Federal Reserve Banks, thereby increasing the growth of $\mathrm{M}_{1}$ in that month. Also, near year-end, the coincidence of European banking holidays with bank reporting dates led to an apparent accumulation of dollar balances by foreign commercial banks at U.S. commercial banks. Uncertainties associated with the energy crists may also hate induced domestic wealth holders to seek refuge for a time in deposit claims of banks and thrift institutions rather than investing in marketable securities. [emphasis added]

The analytical framework implicit in these descriptions of monetary developments suggests that demand forces were an important factor influencing the growth of the money stock in 1973. This approach also holds that shifts in these demand forces would result in undesired changes in short-term interest rates anless at least partially offet.

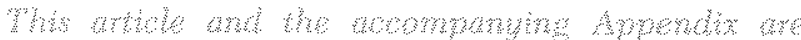

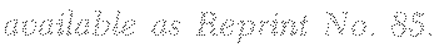

\section{APPENDIX FOMC Decisions in 1973}

With the exception of some footnote references, this Appendix consists entirely of excerpts from the "Record of Policy Actions" of the twelve regularly scheduled Federal Open Market Committee meetings held in 1973. The full "Record" is published in the Federal Reserve Bulletin. The excerpts for each meeting include the Committee's decisions with regard to monetary magnitudes, the "directive" issued to the Federal Reserve Bank of New York, and any dissents from the actions taken. Unless otherwise stated, emphasis has been added by this Bank. Table I provides statements from the "Record" reflecting projections made at each meeting by the Federal Open Market Committee staff with regard to the outlook for real output growth and prices.

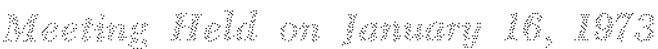

The Committee agreed that the economic situation continued to call for growth in the monetary aggregates over the months ahead at slower rates than those re- corded in the second half of 1972 . The members took note of a staft analysis of prospective reserve-deposit retationships, which suggested that more moderate rates of monetary growth might be achieved in the January. February period by fostering growth in RPD's in that period at an annual rate within a range of 9 to 11 per cent. In view of the very rapid monetary expansion in December, however, the members concluded that open market operations should be directed at achieving still greater restraint and that reserve-stuplying operations that would result in an easing of money market conditions should be avotded unless the annual rate of RPD growth appeared to be dropping below 4.5 per cent. Specifically, they decided that operations should be directed at fostering $\mathrm{RPD}$ growth during the January-February period within a range of 4.5 to 10.5 per cent, while continuing to avoid marked changes in money market conditions.

To implement this policy ... the Committee seeks to achieve bank reserve and money market conditions that will support slower growth in monetary aggregates over the months ahead than occurred in the second half of last year. 


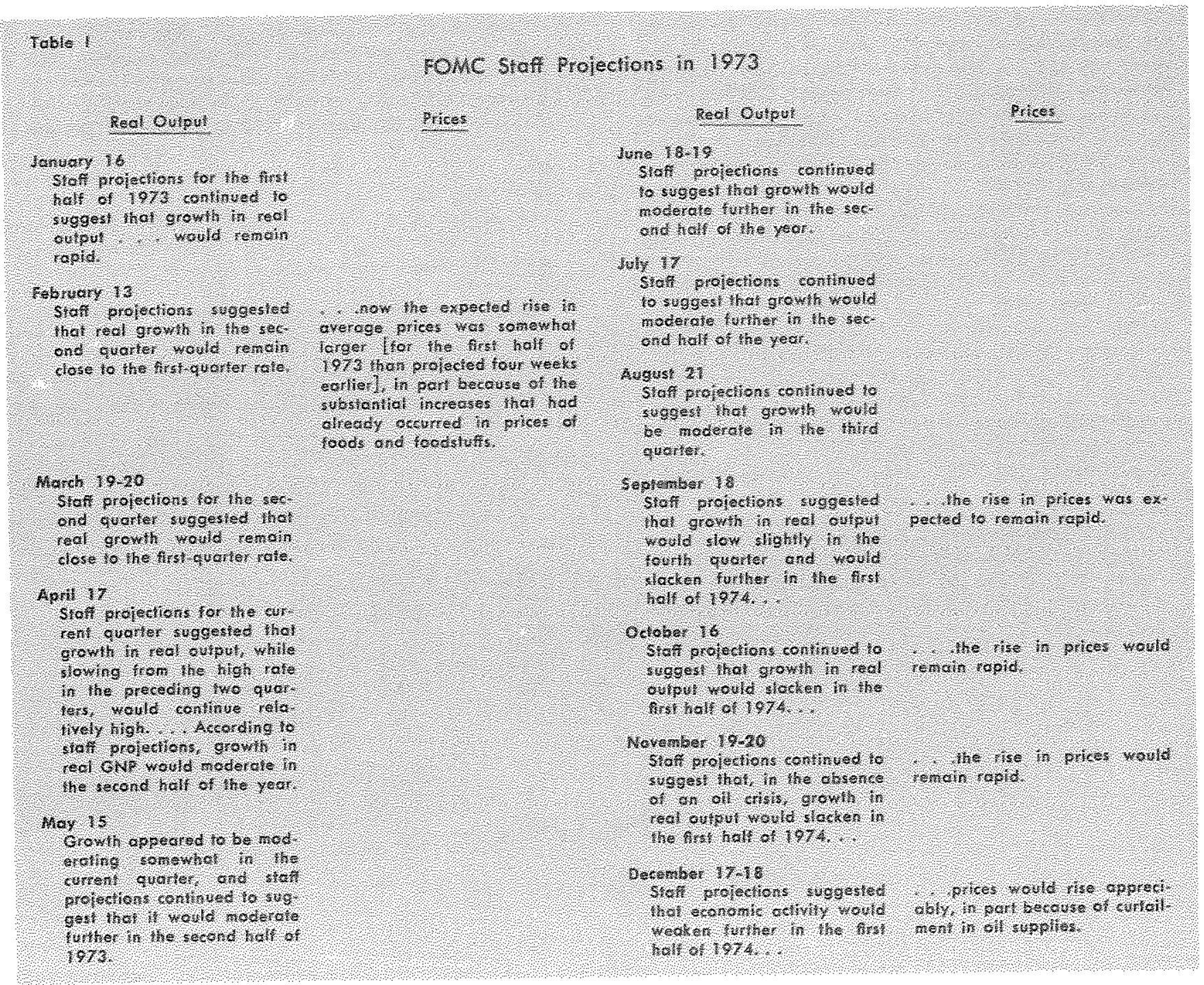

Absent and not voting:

Mr. Hayes

(Mr. Treber voted as his alternate.)

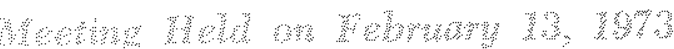

The Committes agreed that the economic situation called for growth in the monetary aggregates over the months ahead at somewhat slower rates than had oc cured on average in the past 6 months. The menbers took note of a staf analysis suggesting that the sharp further advance in shortem interest rates that had occurred in recent months would probaby retard growh in the demand for money over the months ahead. The analysis also suggested that in the February-March period the Committee's objectives for monetary growth

IIr adtition to the "absent ant not voting" category, the "Record" includes a listing of "wotes for this anthon" and "votes against this action." In every case where a vote was cast aganst an action, the subsequent paragraph in the "Theord" and in this summary provides detalls of the dissent. might be fostered by pursuing growh in RPD's at an annul rate whin a range of 0.5 to 2.5 per cent and that attamment of RPD growth in that range probably would be associated wh some additional fiming of money market conditions and some upward pressure on long-tertr interest rates.

The Commitee concluded that actue reservesupplying operations should be woided wress RDD's in the Febriary-March period appeared to be decling at an anmal rate of more than 2.5 per cont. Specifeally, the members decided that operations should be directed at fostering $P P D$ growth dumg that period within a range of -2.5 to +2.5 per cent, whlle continuing to avoid marked charges in money makket conditions.

To mplement this policy . . . the Committee seeks to ahieve bank reserve and money market condi thons that will support somewhat slower growh in nonetory aggregates over the months ahead than occurred on average in the past 6 months.

Absont and not roting;

Mr. Daane 
Early in the intermeeting period ${ }^{2}$ it had appenred that growth in the monetary aggregates would remain strong and that bark sales of CD's, in association with the larger-than-expected demands for bank eredit, might result in growth in RPD's in the Febrtary-March period at an annual rate in excess of 2.5 per cent. Consequently, the System had acted prompty to slow the expansion in RPD's, and the Federal funds rate rose to about $6 \% / 4$ per cent for the statement week ending February 21 from around $6 \%$ per cent in the days before the webnary meeting. After March 1 when Committee members agreed that the weekly average rate for Federal funds should be permitted to rise somewhat fumher if necessary to limit growis in RPD's - the rate fuctuated around a level stighty above 7 per cent.

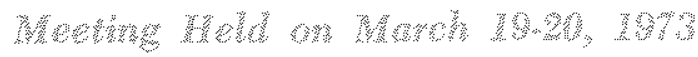

The Committee agreed that the economic situation called for growth in the monetary aggregates over the months ahead at somewhat slower rates than had occurred on the average in the past 6 months. The mem* bers took note of a staff analysis suggesting that the cumulative impact of the advance in short-term interest rates that had already occured would probably slow growth in the monetary aggregates over the months ahead. Nevertheless a relavely rapid rate of growth in RPD's was projected for the March-April period, chiely because the substantial increase in the outstanding volume of largendenomination CD's that had occurred in recent weeks would affect recuired reserves with a lag and further expansion in the outstanding volume was expected. Therefore, the Committee's objectives for monetary growth might be fostered by pursuing growh in APD's in the March-Aprit period at an amnal rate within a range of 14 to 16 per cent. The analysis also suggested that attainment of RPD growth in that range might be associated with some further increase in some shortterm interest rates and probably also in longmern rates.

The Committee concluded that active reserve-supplying operations should be limited unless RPD's in the March-April period appeared to be growing at an annul rate of less than 12 per cert. Specincally, the members decided that operations should be directed at fostering RPD growth during that period at a rate within a range of 12 to 16 per cent, while continuing to avoid marked changes in money market condinions.

To implement this policy . . the Commitee seeks to achieve bank reserve and money market conditions that will support somewhat slower growth in monetory aggrogates over the months ahead than occurred on average in the past 6 months.

On April 11, 1973, less than one week before the date scheduled for the Committee's next meeting, the System Account Manager reported that in light of the latest estimates for $\mathrm{MPD}$ 's and the monetary aggregates, he interpreted the Committee's instructions to call for rem serve-supplying operations consistent with cheasing in

2This paragraph was excerpted from the Narch "Record." money market conditions. On that day a mainty of the members concurred in a recommendation by the Chatrman that such operations not be underaken prior to the next meeting, when the Committee would have an opportunity to deliberate on the appropriate policy course.

Ot March 15,1973 , Commitee members had voted to increase from $\$ 2$ billon to $\$ 3$ billion the linit on changes between Committee meetings in System Acconnt holdings of U.S. Goverment and Federal agency sectrities specined in paragraph 1 (a) of the contrining authorty drective with respect to domestic open matke operations, effective immediately, for the period endmg win the close of business on Mareh $20,1973$.

Absent and not voting:

Messrs. Bums, Daane, and Sheehan

This action, which was ratifed by unanimous vote at this meeting, had been taken on recommendation of the System Account Manager. The Manager had advised that a substantal wolume of open market purchases of Treasury and Federal agency securties hat been required in the period since the Commitree's previous meeting in order to ofset the reserve absorption caused by a sizable unanticipated rise in reasury balances at Federal Reserve Banks, an increase in currency in circulation, and changes in certain other market factors, and that a temporary increase in the leeway for System purchases appeared desirable in light of the prospective near-term needs to supply reserves.

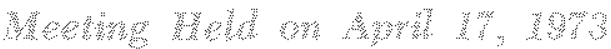

The Commites agred that the economic situation and prospects called for moderate growih the monetary aggregates over the months ahead, continumg the policy course agreed wpon at the preceding meeting. The members took note of a staft analysis suggesting that the demand for money was likely to be stronger over the near tom than it had been in the frst quarter of the year, reflecting the unvisully large Federal tax refunds - which would add to demand deposits tomporarlyand continued strong expansion in economit activity. Alhough it was likely that expansion in the outstanding volume of large-denomination $C D$ s would slow from the rapid pace in February and March, the increase was still expected to be large. Therefore, a relatively rapid rate of growth in RPD's in the April-May period was projected to be consistent with moderate growth in the monetary aggregates over the months ahead. The anal ysis also suggested that such a rate of growth in RD's might be associated with lithe change in money narket conditions and short-term interest rates in general.

The Commitee decided that operations should be directed at fosteng PPD growin during the April-hay period at an mmial rate whin a range of 10 to 12 per cent, while continuing to avoid makked changes in money market conditions.

To implement this poticy. . The Commitee seeks to acheve bark reserve and money merket conditions consistent with moderate growth in monetary aggregates wer the morths ahead. 
Absent and not voting:

Mr. Mayo

(Mr. Winn voted as his alternate)

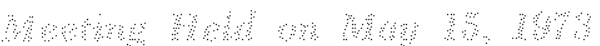

The Committee agreed that the economic situation and prospects called for somewhat slower growth in the nonetary aggregates over the months immediately ahead than had occurred on average in the past 6 months. A staff analysis suggested that the unusually large refunds of Federal personal income taxes had added temporarily to both demand deposits and consumer-type time and savings deposits and that as such refunds diminished growth in the demand for money would tend to moderate in the period immediately ahead. The analysis also suggested that the lagged effects of recent increases in interest rates would work in the direction of moderating the demand for money. Faced with sustained strong demands for credit, banks were likely to continue to increase substantially the outstanding volume of large-denomination CD's. Therefore, according to the analysis, relatively rapid growth in RPD's in the May-June period was likely to be consistent with somewhat slower growth in the monetary aggregates than had occurred on average over the past 6 months. The stafe analysis also indicated that such a slowing in monetary growth would probably be associated with further increases in short-term interest rates and also with some rise in longer-term rates.

The Committee decided that operations should be directed at fostering $\mathrm{RPD}$ growth during the May-June period at an annual rate within a range of 9 to 11 per cent, while continuing to avoid marked changes in money market conditions. . . . It was understood that the Chaiman might call upon the Committee to consider the need for supplementary instructions before the next scheduled meeting if significant inconsistencies appeared to be developing among the Committee's various objectives and constraints; the chance seemed greater than usual that such consultation would be needed.

To implement this policy . . the Committee seeks to achieve bank reserve and money market conditions consistent with somewhat slower growth in monetary aggregates over the months immediately ahead than occurred on average in the past 6 months.

\section{Absent and not voting: \\ Mr. Mitchell}

Soon after the May meeting; ${ }^{3}$ it had appeared that in the May-yne period the monetary aggregates would grow at rates in excess of acceptable ranges and that $\mathrm{APD}$ 's would grow at an anmual rate above the range that the Committee had specified. Consequently, the System had acted promptly to resist the expansion in RPD's, and the Federal funds rate rose from around $73 / 4$ per cent in the days before the May meeting to an average slightly above 8 per cent in the statement week ending May 23 .

3This paragraph was excerpted from the June "Record"
On May 24 and again on Iune 8 , a majority of the Committee members concurred in recommendations by the Chairnan that money market condtions should be per. mitted to tighten still further if necessary to limit growth in RPD's, and the Federal funds rate rose to around 812 per cent in the days before this meeting.

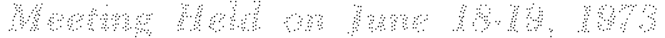

The Committee agreed that the economic situation and prospects called for somewhat slower growth in monetary aggregates over the months immediately ahead than appeared indicated for the first half of the year. A staff analysis suggested that expansion in the demand for money was likely to slow considerably from the high rate indicated for the second quarter in response to the anticipated moderation in GNP growth, to the sharp rise in short-term interest rates that had occurred in recent months, and to the running down of the deposits that had been built up in association with the unusually large refunds of Federal income taxes in the second quarter. .. It was noted, however, that projections of the demand for money were subject to more uncertainty than usual because of the unknown effects of the short-term freeze on prices and the lack of information concerning the elements of the price and wage stabilization program to follow. ...

In view of the rapid monetary expansion in the second quarter and uncertainty about the demand for money in the months ahead, the Committee agreed that the lower end of the range specified for the annual rate of RPD growth in the June-July period should be lower than that projected in the staff analysis. Specifically, the members decided that operations should be direeted at fostering RPD growth during that period at an annual rate within a range of 8 to 11.5 per cent. They agreed that money market conditions might be permited to vary somewhat more in the inter-meeting period than had been contemplated at other recent meetings, if such variation appeared indicated in the conduct of operations directed toward achieving RPD growth in the desired range.

To implement this policy . . the Committee seeks to achieve bank reserve and money market con" ditions consistent with somewhat slower growth in monetary aggregates over the months inmediately ahead than appears indicated for the first half of the year.

Absent and not voting: Messrs. Balles and Hayes

(Messrs. Clay and Debs voted as altemates for Messrs. Balles and Hayes, respectively.)

Soon after the June meeting," available data suggested that in the June-July period RPD's would grow at an annual rate above the range that the Committee had specified and that $M_{1}$ would grow at a rate in excess of an acceptable range. Data that became avalable after the July 4 holiday continued to suggest excessive strength

tThis paragraph was excerpted from the July "Record." 
in RPD's and the monetary aggregates in the June-July period, even though money market conditions had continued to tighten, and on Friday, July 6, a majority of Committee members concurred in a recommendation by the Chairman that money market conditions should be permitted to tighten to a greater extent than had been contemplated at the June meeting. The Federal funds rate, which had been about $83 / 4$ per cent in the days before the June meeting, was close to $93 / 4$ per cent during most of the week preceding this meeting, and in the last few days it had risen further.

On July 6, 1973, Committee members voted to increase from $\$ 2$ billion to $\$ 3$ billion the limit on changes between Committee meetings in System Account holdings of U.S. Government and Federal agency securities specifed in paragraph 1 (a) of the authorization for domestic open market operations, effective immediately, for the period ending with the close of business on July 17,1973 .

Absent and not voting:

Messrs. Bucher, Daane, Hayes, Mayo, and Morris

(Messrs. Debs and Winn voted as alternates for Messrs. Hayes and Mayo, respectively.)

This action was taken on recommendation of the System Account Manager. The Manager had advised that a substantial volume of open market purchases of securities had been required in the period since the Committee's meeting on June 19 in order to offset the reserve absorption caused by a rise in "Treasury balances at Federal Reserve Banks, an increase in currency in circulation, and a decine in Federal Reserve float, and he further advised that a temporary increase in the leeway for System purchases appeared desirable in light of the prospective near-term needs to supply reserves.

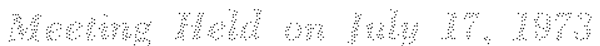

The Committee agreed that the economic situation and prospects called for slower growth in monetary aggregates over the months immediately ahead than had occurred on average in the first half of the year. A staff analysis suggested that expansion in the demand for money was likely to slow considerably from the high rate recorded in the second quarter - in response to the anticipated moderation in GNP growth and to the sharp rise in short-term interest rates that had occurred in recent months.

To implement this policy. . . the Committee seeks to achieve bank reserve and money market conditions consistent with slower growth in monetary aggregates over the months immediately ahead than occurred on average in the first half of the year.

Absent and not voting:

Mr. Mitchell

Mr. Francis dissented from this action not because he disagreed with the objectives of the policy adopted by the Committee but because he believed that - as had proved to be the case following other recent meetings the objectives would not be achieved because of the constraint on money market conditions.

During the frot 2 weeks after the July meeting, available data had suggested that in the fuly-August period RPD's would grow at a rate above the range that the Committee had specified and that the monetary aggregates would grow at rates in excess of an acceptable range. Therefore, the System had acted promptly to limit expansion in RPD's, and the Federat funds ratewhich had averaged around $10 \% / 4$ per cent in the statement week ending July 18 - rose to around $101 / 2$ per cent in the next two statement weeks.

On August 3 , a majority of the Commitiee members had concurred in a recommendation by the Chairman that money market conditions should be permitted to tighten still further if necessary to limit growth in RPD's and in the monetary aggregates, but in light of subsequent developments, tighter conditions were not sought and the funds rate remained close to $101 / 2$ per cent.

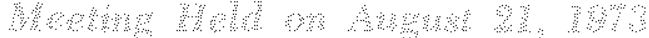

The Committee agreed that the economic situation and prospects called for slower growth in monetary aggregates over the months immediately ahead than had occurred on average thus far in 1973. A staff analysis suggested that despite the substantial growth expected in nominal GNP the demand for money in the period ahead would be limited by the sharp rise in short-term interest rates that had occurred in recent months. In the immediate future, moreover, monetary growth was likely to be restricted by a downward adjustment in the piblic's demand for cash balances in response to the increases in rates paid on time and savings deposits.

To implement this policy. . the Committee seeks to achieve bank reserve and money makket conditions consistent with slower growth in monetary aggregates over the months immediately ahead than has occurred on average thus far this year.

Absent and not voting:

$$
\text { Mr. Mitchell }
$$

Mr. Francis dissented from this action, although he agreed with the objectives of the policy adopted by the Committee, because he could not accept the constraint placed on money market conditions.

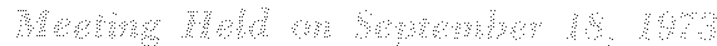

The Committee agreed that the economic situation and prospects called for moderate growth in monetary aggregates over the months ahead. A staff analysis indicated that, although transactions demands for money

5This paragraph was excerpted from the August "Record."

"This paragraph was excerpted from the August "Record," The July "2ecord" notes, "On August 3, 1973 , the available men" bers - with the exception of Messrs. Bucher and Sheehan concurred in a recommendation by the Chairman that money market conditions should be permitted to tighten still further if necessary to linit growth in RPD's." 
probably would expand, growth in the money stock in the months ahead was likely to be limited in lagged response to the rise in short-term interest rates that had occurred in recent months. Consequently, achievement of moderate growth in monetary aggregates within an acceptable period of time was likely to require some easing in money market conditions. In the current environment of tnusual sensitivity of expectations in financial markets, however, signs that monetary policy was moving toward a significant easing in money market conditions might result in large expectational declines in short-term interest rates and also in further declines in long-term rates, tending to erode the existing degree of monetary restraint

In view of the relatively weak behavior of the monetary aggregates in August and prospects for limited expansion in the months immediately ahead, the Committee concluded that reserve-supplying operations should not become restrictive unless RPD's in the September-October period appeared to be growing at an annual rate of more than 18 per cent. Specifically, the Committee decided that operations should be directed at fostering RPD growth during that period within a range of 15 to 18 per cent, while taking account of deviations in monetary growth from an acceptable range and avoiding unduly sharp changes in money market conditions. Although the members recognized that pursuit of the objective for RPD's might be associated with some easing in money market conditions, a number of them cautioned against the risk of generating market impressions that monetary restraint was being relaxed significantly, and it was agreed that, in the conduct of operations, account should be taken of domestic financial market developments.

To implement this policy . . , the Committee seeks to achieve bank reserve and money market conditions consistent with moderate growth in monetary aggregates over the months ahead.

Absent and rot voting:

Messrs. Brimmer and Hayes

(Mr. Debs voted as alternate for Mr. Hayes.)

On October 1 the Account Manager reported that sig. nificant inconsistencies existed among the Committee's various objectives and constraints, and the Cormmittee held a telephone meeting on October 2.

Following the telephone meeting, at which the majority of the members concluded that money market conditions should be allowed to ease somewhat it such easing did not threaten to reinvigorate the sharp rally in markets for short-term securities, the System became somewhat more aggressive in supplying reserves. . .

On October 10 the Committee held another telephone meeting, at which the members agreed that in the few days remaining until this meeting, reserves should be supplied at a rate consistent with some easing in money matket conditions beyond that decided upon on October 2.

TThe following three paragraphs were excerpted from the Oetober "Record."

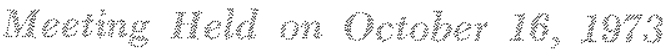

At this meeting the Committee agreed that the economic situation and prospects continued to call for moderate growth in monetary aggregates over the months ahead. A staff analysis indicated that, although the transactions demand for money would probably expand, the sharp rise in shorterm interest rates that had occurred through early September would tend to dampen the demand for money in the months ahead. Consequently, achievement of moderate growth in monetary aggregates was likely to require some easing in money market conditions. . . .

In view of the weak behavior of the monetary aggregates in August and September, the Committee concluded that reserve-supplying operations shotld not become restrictive unless RPD's in the October-November period appeared to be growing at an annual rate of more than 5 per cent. Specifically, the members decided that operations should be directed at fostering RPD growth during that period within a range of 2 to 5 per cent, while avoiding unduly sharp changes in money market conditions.

To implement this policy . . . the Committee seeks to achieve bank reserve and money market conditions consistent with moderate growth in monetary aggregates over the months ahead.

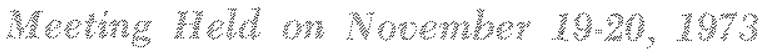

The Committee agreed that the economic situation and prospects continued to call for moderate growth in monetary aggregates over the months ahead. A staff analysis suggested that in the near term the demand for money would expand in response to the sizable increase in nominal GNP estimated for the fourth quarter and to the uncertainties generated by the oil shortage. . . . While the outstanding volume of large-denomination CD's was expected to expand toward the end of the year in response to a renewal of growth in business loans at banks, it was anticipated that required reserves against such CD's would drop further in the November-December period. Consequently, negative growth in RPD's in that period - at an annual rate within a range of -1 to -3 per cent - was thought likely to be consistent with moderate growth in both the namowly and the more broady defined money stock over the months ahead. It was expected that such a change in RPD's would be associated with little change in money market conditions.

To implement this policy. . . the Committee seeks to achieve bank reserve and money market conditions consistent with moderate grouth in monetary aggregates over the months ahead.

Mr. Morris dissented from this action because he felt that in view of the marked deterioration in the economic outlook that had occurred over the past few weeks, stemming from the energy crisis, a modest move in the direction of a more stimulative monetary policy was appropriate.

Subsequent to the meeting it appeared that in the November-December period growth in the monetary ag- 
gregates might exceed acceptable ranges. In view of that behavior, the System, under ordinary circumstances, would have become somewhat more restrictive in its reserve supplying operations, expecting that money market conditions would tighten somewhat. On November 30 , however, the available members concurred in a recommendation by the Chaiman that, in light of current uncertainties regarding the economic outlook and the sensitive state of financial market psychology, the System aim to naintain current money market conditions for the time being.

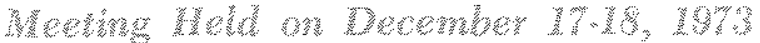

The Committee concluded that the economic situation and outlook called for a modest easing of monetary policy. The members decided that for the period until the next meeting somewhat more emphasis should be placed on money market conditions than had been the case in recent months; specifically, they decided that operations should be directed toward achieving some easing in bank reserve and money market conditions, provided that the monetary aggregates did not appear to be growing excessively. Taking into account the staft analysis, the members expected that pursuit of that objective would be consistent with growth in RPD's in the December-January period at an annual rate within a range of $8 \frac{1}{4}$ to 11 per cent.

To implement this policy . . . the Committee seeks to achieve some easing in bank reserve and money market conditions, provided that the monetary aggregates do not appear to be growing excessively.

Absent and not voting:

Mr. Francis

(Mr. Kimbrel voted as alternate for $\mathrm{Mr}$. Francis.)

Mr. Hayes dissented from this aoton because, with the problems of inflation increasing rather than abating and with the monetary aggregates apparently growing more rapidly in 1973 than the Commitee had considered desirable, he favored a continuation of the current degree of monetary restraint without noticeable relaxation unless signs of weakening in the economy became more apparent. He believed that, while there was not much that monetary policy could do to relieve the economic problems arising from the oll shortage, a premature easing of policy cotld exacerbate the problems of inflation.
Subsequent to the meoting it appeared that in the December-January period the anmual rate of growth in RPD's might be close to the upper limit of the range that had been specified by the Committee and that rates of growth in $M_{1}$ and $M_{2}$ might exceed acceptable ranges, although a significant part of the growth in the monetary aggregates could be attributed to an unanticipated increase in deposits of foreign commercial banks at U.S. banks. On January 11 the available nembers - with the exception of Mr. Francis - concurred in a recommendation by the Chaiman that, in view of the sensitive state of fmancial markets and the general economic situation, the System aim to maintain prevailing money market conditions for the time being.

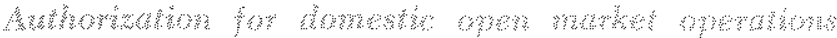
On January 4, 1974, a majority of Committe members voted to increase from $\$ 2$ billion to $\$ 3$ billion the limit on changes between Committe meetings in System Account holdings of U.S. Government and Federal agency securi ties specified in paragraph 1 (a) of the authorization for domestic open maket operations, effective immediately, for the period ending with the close of business on January 22,1974 .

Absent and not voting:

Messrs. Balles, Bucher, and Daane

(Mr. Clay voted as alternate for Mr. Balles.)

This action was taken on recommendation of the System Account Manager. The Manager had advised that a substantial wolume of open market purchases of securities had been required in the period since the Committee's meeting on December 18, 1973, in order to offset reserve absorption resulting from market factors and that a near-term need to supply reserves was in prospect; he had further advised that strength of the dollar in foreign exchange markets suggested that foreign official sales of U.S. Treasury bills migh be heavy and that the System should be in a position to acquire some of those bills while offsetting any undesired effects on bank reserves by other means.

Mr. Francis dissented from this action because, in view of his concern over the continuing rapid rate of growth in the monetary aggregates, he preferred that additional reserves necessary to meet requirements over the next few weeks be obtained through member bank borrowings rather than provided through additions to System holdings of securities. Moreover, he believed that foreign offcial sales of Treasury bills should be absorbed in the market.

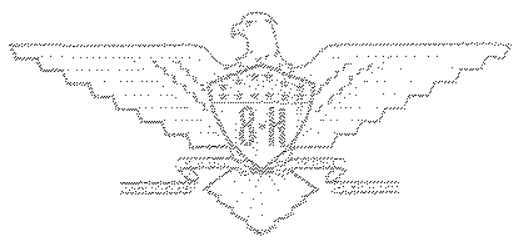

